
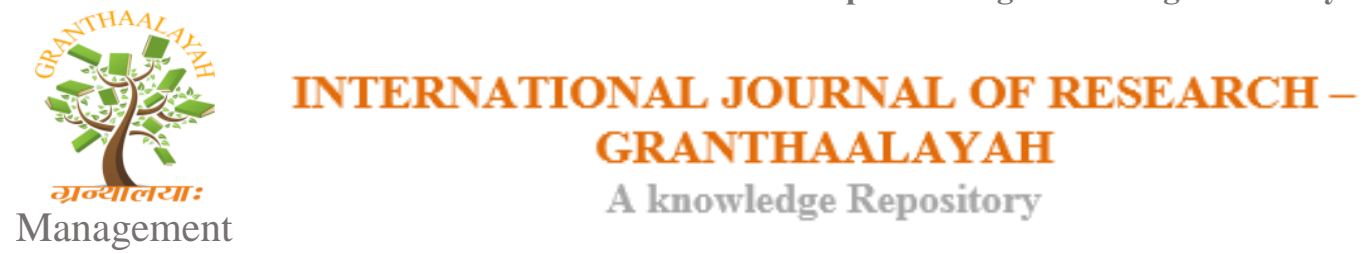

\title{
THE INFLUENCE OF M-COMMERCE SERVICE AND SYSTEM QUALITY DIMENSIONS ON OVERALL PERCEIVED SERVICE QUALITY
}

\author{
Anas Abdelsatar Salameh"1, Shahizan Bin Hassan², Jamal Mohammad Alekam ${ }^{3}$ \\ ${ }^{*}$ Universiti Utara Malaysia, School of Technology Management \& Logistics, Othman Yeop \\ Abdullah (OYA) Graduate School of Business, Box.06010. Kedah. Malaysia \\ ${ }^{2}$ Universiti Utara Malaysia, School of Technology Management \& Logistics, Othman Yeop \\ Abdullah (OYA) Graduate School of Business, Box.06010. Kedah. Malaysia \\ ${ }^{3}$ Universiti Utara Malaysia, School of Business Management, Othman Yeop Abdullah (OYA) \\ Graduate School of Business, Box.06010. Kedah. Malaysia
}

\section{ABSTRACT}

Information Technology (IT) has an increasing importance and development in business life. Nowadays, businesses have been seeking to reach their customers through m-services especially m-commerce. The concern is to what extent this m-commerce system can satisfy the consumers' needs and contributes to the overall online purchasing development. This study aims to examine the effect of m-commerce service quality dimensions (website design, responsiveness, and trust), and system quality dimension (accessibility) on overall perceived service quality in $m$-commerce by customers. The data were collected from the Arab Open University in Jordan through a selfadministered questionnaire, in order to test the hypotheses of the proposed model. 618 of questionnaires were used for analysis data, out of 870 distributed. The result of this study revealed that there are a significant effect of responsiveness and accessibility on overall perceived service quality. This study has some important implications for business practice and research.

Keywords:

Service quality, system quality, m-services, mobile commerce, overall perceived service quality.

Cite This Article: Anas Abdelsatar Salameh, Shahizan Bin Hassan, and Jamal Mohammad Alekam, "THE INFLUENCE OF M-COMMERCE SERVICE AND SYSTEM QUALITY DIMENSIONS ON OVERALL PERCEIVED SERVICE QUALITY" International Journal of Research - Granthaalayah, Vol. 3, No. 8(2015): 1-13.

\section{INTRODUCTION}

Most businesses nowadays depend on Information Technology (IT) to manage their operations. With IT, it is easier and quicker to access the consumer and deliver what the consumer has ordered for or meet their needs (Alfawaer, Awni, \& Al-Zoubi, 2011). Companies are increasingly turning to the Internet to market products and services. However, the effectiveness of such online 
commerce systems depends on the degree of comfort that customers feel with the technologybased interactions between the customers and companies. Service in e-commerce is a function of how the online store facilitates efficient and effective shopping, purchasing and delivery of products and services.

Since e-commerce mostly depends on the availability of a wired network connection to the Internet, there is still a limitation to this service among customers and corporate professionals who are constantly on the move. In order to overcome such a limitation, there is an inclination to make use of wireless networking technologies which can provide potential commerce at anytime and anywhere. The move from wired to wireless services is a remarkable sign for the new millennium (Landers, 2002). From the literature, it is evident that evolving $\mathrm{m}$-commerce service has many potential implications. According to Tiwari, Buse and Herstatt (2006), m-commerce, on the basis of the features make provision for additional value-added utility particularly. This study aims to examine the effect of m-commerce service quality dimensions (website design, responsiveness, and trust), and system quality dimension (accessibility) on overall perceived service quality (OPSQ) of m-commerce based on the perceptions of Arab Open University (AOU) students and employees.

\section{LITERATURE REVIEW, THEORETICAL FRAMEWORK AND HYPOTHESES DEVELOPMENT}

\subsection{SERVICE QUALITY IN M-COMMERCE}

Review of extant literature has shown that articles that measure the impact of Service Quality (SQ) in $\mathrm{m}$-service are scarce. Many of the few that are however available only studied $\mathrm{m}$-commerce SQ by examining the behavior of customers (Gerpott et al., 2001, Kim et al. 2004, Lim et al., 2006, Seth et al., 2005, Turel and Serenko 2006). For instance, Turel and Serenko (2006) while studying customer satisfaction in to m-services in Canada adapted the American Customer Satisfaction Model (ACSM) (Fornell et al., 1996). In their study, the authors defined perceived quality, which is also perceived SQ, as the served market's evaluation of service usage experience in the recent time after which personalization and service reliability were used for measurement (Turel and Serenko 2006).

Studies by Kim et al. (2004) recognized six service quality measures (Gerpott et al. 2001, Lee et al. 2001) such as pricing structure, call quality, mobile devices, convenient procedures, value added services and customer support. However, factors, such as convenient procedures, customer support and mobile devices were later removed because of items with low factor loadings using exploratory factor analysis. Consequently, SQ was measured by the remaining three factors (Kim et al. 2004). In the same vein, Lim et al., (2006) equally identified pricing plans, data services, customer service, network quality and billing systems as the five dimensions of consumers' perceived quality of m-services. These factors were confirmed through exploratory factor analysis (Lim et al., 2006). Furthermore, there are other studies that examined how SQ relates to various m-service applications (Kar et al., 2006, Rao and Minakakis 2003, Yun et al., 2005).

Chae et al., (2002) in the course of examining m-service information quality, extended a prior framework of information quality of Dey (2001) and Wang (1998) by incorporating the features 
of m-commerce such as mobile context and devices. While measuring m-commerce information quality they came up with four dimensions which include connection quality that eventually influenced by responsiveness and stability, content quality as influenced by believability, objectivity, interaction quality, amount and contextual quality which were determined by navigation, structure, presentation, promptness and timeliness. Furthermore, the study maintained that the relationship between the four major dimensions of information quality and user satisfaction was moderated by a customer's intended goal (Chae et al., 2002). In another study, Kar et al. (2006) considered the unstable environment in which m-services were provided and adapted as the quality dimensions of e-services. The models of Kaynama and Black (2000) and Liljander et al. (2002) were developed using SERVQUAL for the purpose of aligning with the features of mservices. In these studies, user interface, responsiveness, reliability, customization and trust were identified as the five dimensions of SQ. Yun et al. (2005), in addition examined ring back tone, SMS, melody ring, background image service, gaming context based services, video on demand and multimedia message services as dimension of SQ in the context of mobile data services. The core quality attributes identified are: sound quality, play time, and image quality.

\subsection{ISSUES AND BARRIERS RELATED TO THE M-COMMERCE DEVELOPMENT}

According to E-paymentsMerchantInitiative (2011); Euromonitor (2011); Jahanshahi, Mirzaie, \& Asadollahi (2011); and Goi \& Ng (2011), there are many problems and obstacles in facing the development of m-commerce service. Some of these problems listed as follows:

(i) Consumers are concerned with privacy in using the mobile device for transactions;

(ii) Consumers are still not confident in using mobile devices to make payment. Since some personal data must be provided to enable the goods and services to be delivered, consumers feel reluctant to engage in on-line transactions;

(iii)Consumers do not trust the web merchant; and

(iv) Security is also a concern for consumers.

\subsection{SERVICE QUALITY DIMENSIONS}

\subsubsection{WEBSITE DESIGN}

Website design refers to the appearance of mobile portal and is consistent with the tangibility dimension in the SERVQUAL model. While Parasuraman et al., (1988) defined a tangible dimension as the physical appearance, such as facilities, equipment, and personnel, many researchers replaced this definition with the user website required for adapting to the e-service context (O'Cass \& Carlson, 2012; Udo, Bagchi \& Kirs, 2010; Loiacono et al., 2002; Wolfinbarger \& Gilly, 2003; Lee \& Lin, 2005; Aladwania \& Palvia, 2002; Riel et al., 2001). Ghose and Dou (1998) argued that greater attractiveness of a website increases the level of user satisfaction. Website design is very important in the m-commerce service environment, because the website substitutes the role of customers' contact in the physical commercial companies. On the overview, website design is a vital factor that determines the customer-perceived mobile commerce SQ. It has significant and positive impacts on the customers' perceived SQ. The related hypothesis we intend to test is stated as follows:

H1: There will be a significant positive relationship between website design and overall customer perceived service quality. 


\subsubsection{RESPONSIVENESS}

The second dimension is responsiveness which is similar to the responsiveness dimension in the SERVQUAL model. The SERVQUAL model (Parasuraman et al., 1988) defines responsiveness as employees' willingness in the provision of prompt service and dealing with consumer complaints. Wang (2003) stated that: "responsiveness" is a measure for the company's ability in supporting customers with the appropriate information when a problem occurs. It is also the mechanism that handles returns, and has the capacity of executing arrangement for online guarantees. Responding quickly to customers' request indicates that the company is customeroriented. Subsequently, this can subdue the issue of uncertainty and thus increase the perceived convenience of customers (Gummerus et al., 2004; Wolfinbarger \& Gilly, 2003). The corresponding hypothesis is:

$\mathrm{H} 2$ : There will be a significant positive relationship between responsiveness and overall customer perceived service quality.

\subsubsection{TRUST}

According to Lynch and Lundquist (1996), e-service with much academic discourse surrounding the security, privacy, and confidence centers on Trust. This is similar to the assurance dimension in the SERVQUAL model. Kimery and McCard (2002) argued that "trust is the user's willingness to accept the vulnerability of an online transaction based on their positive expectations regarding future online provider behaviors". Reichheld and Schefter (2000) pointed out that trust is a significant antecedent of participation in online settings because of the increased ease with which online transaction can behave opportunistically. Based on this prior support, we propose the following:

H3: There will be a significant positive relationship between trust and overall customer perceived service quality.

\subsection{SYSTEM QUALITY DIMENSION}

\subsubsection{ACCESSIBILITY}

In traditional marketing literature, speed of delivery is defined as the time it takes to actively perform the service (Dabholkar, 1996). Maister (1985) argued that if consumers perceive that service is delivered quickly, they are likely to evaluate the service more highly. In the e-services environment, speed of access may also be an important factor to lure users to a particular website (Cho \& Park, 2001; Sohn, 2000).

However, accessibility in the m-commerce environment refers to the availability of the system, where and when the customers need to conduct any kind of commercial transactions. The potential benefit of using an m-commerce system cannot be successfully achieved without having reliable speedy online access, because customers expect the m-commerce services to be available on demand. M-commerce applications and services depend heavily on the underlying network support. Two of the most significant factors that influence the development and the quality of $\mathrm{m}$ commerce services are the available bandwidth offered by the wireless networks as well as network coverage (Papanikolaou \& Mavromoustakos, 2006; Siau, Lim, \& Shen, 2001). Thereafter, 
accessibility is one of the substantial dimensions of the mobile SQ, and has positive significant impacts on the customers' perceived SQ. Building upon this prior work, we propose hypothesis H4 as follows:

H4: There will be a significant positive relationship between accessibility and overall customer perceived service quality.

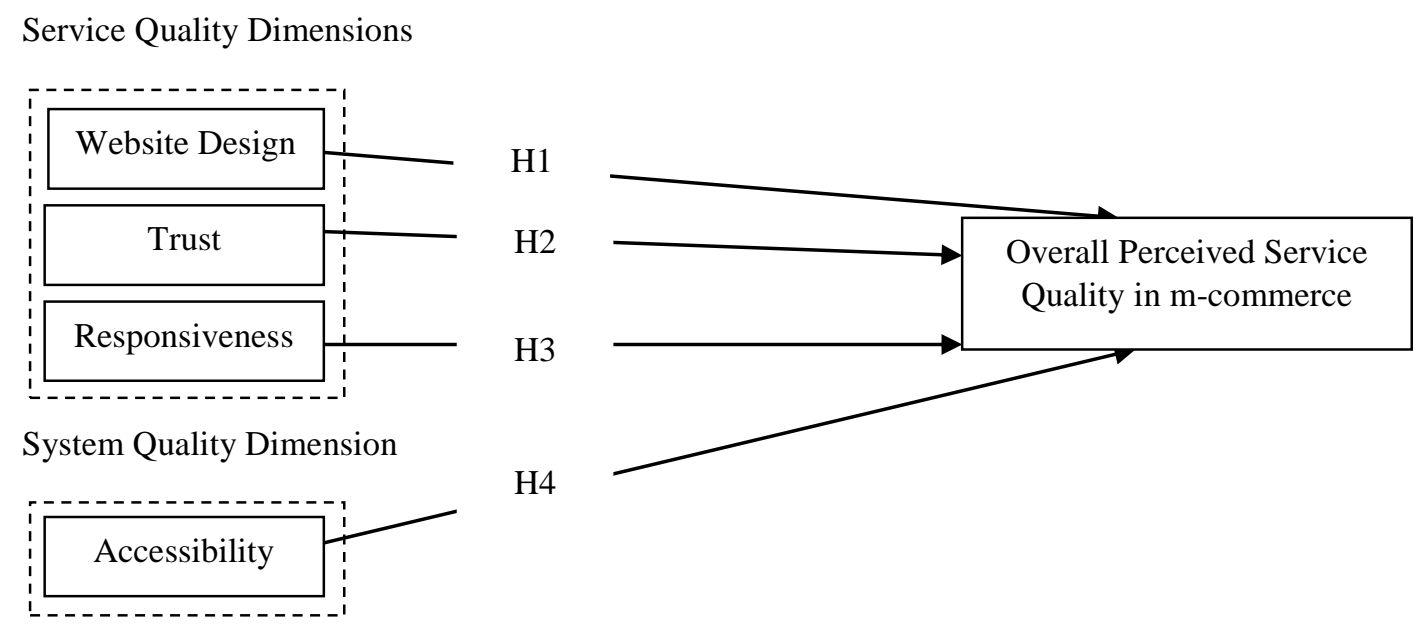

Figure 1: Proposed Research Framework

\section{METHODOLOGY}

\subsection{RESEARCH GOAL}

In this study, we aim to examine the effect of m-commerce service quality dimensions (website design, responsiveness, and trust), and system quality dimension (accessibility) on overall perceived service quality in m-commerce by customers. A structured questionnaire was used in order to gather the data to develop the mobile service quality scale.

\subsection{SAMPLE AND DATA COLLECTION}

In the current study, the sample of this study was the university students and employees. The data was collected via a self-administered questionnaire of AOU University. Previous studies revealed that mobile services are popular among young students and people (Kinnally et al., 2008). The questionnaire which is meant to measure the overall perceived service quality in m-commerce, was distributed to 870 targeted respondents, randomly selected from colleges of AOU University. Out of that number, 618 were returned and used for the analysis.

\subsection{RESEARCH ANALYSIS AND RESULTS}

PLS (partial least square) procedure which is Structural Equations Modeling SmartPLS 2.0 was used for the purpose of developing the reliability prior to the evaluation of the model and PLS is also used to test the hypotheses. 


\subsubsection{THE MEASUREMENT MODEL}

The content validity and the construct validity were confirmed, in order to establish the goodness of measurement, as discussed below:

\subsubsection{THE CONTENT VALIDITY}

The content validity of a construct implies that all the items used to measure a construct should show high loadings on their respective constructs. This is as defined in the multivariate analysis literature. In other words, the measuring constructs must load higher comparing to other constructs in the same column and row. Therefore, following the suggestion of Hair et al., (2010) and Chin (1998), the factor loading should be used to evaluate the content validity. This implies that if some items have higher loadings on other constructs that the ones they belong to, these items will be candidates for deletion. Tables 1 and 2 showed that all the variables significantly loaded on their respective constructs and this confirmed that the measurement model used possesses the required content validity.

Table1: Loading and cross-loadings of the items

\begin{tabular}{|c|c|c|c|c|c|c|}
\hline Constructs & Items & WEB & TRST & RESP & $\mathrm{ACC}$ & OPSQ \\
\hline \multirow{5}{*}{ Website Design } & WEB1 & 0.574 & 0.379 & 0.158 & 0.253 & 0.217 \\
\hline & WEB2 & 0.630 & 0.262 & 0.083 & 0.231 & 0.095 \\
\hline & WEB3 & 0.804 & 0.387 & 0.188 & 0.277 & 0.276 \\
\hline & WEB4 & 0.783 & 0.362 & 0.114 & 0.250 & 0.212 \\
\hline & WEB5 & 0.717 & 0.495 & 0.260 & 0.358 & 0.316 \\
\hline \multirow{6}{*}{ Trust } & TRST1 & 0.332 & 0.782 & 0.167 & 0.351 & 0.255 \\
\hline & TRST2 & 0.288 & 0.802 & 0.159 & 0.460 & 0.316 \\
\hline & TRST3 & 0.355 & 0.833 & 0.272 & 0.386 & 0.331 \\
\hline & TRST4 & 0.355 & 0.630 & 0.356 & 0.321 & 0.324 \\
\hline & TRST5 & 0.463 & 0.751 & 0.337 & 0.366 & 0.314 \\
\hline & TRST6 & 0.327 & 0.690 & 0.247 & 0.391 & 0.199 \\
\hline \multirow{4}{*}{ Responsiveness } & RESP1 & 0.412 & 0.478 & 0.775 & 0.279 & 0.334 \\
\hline & RESP2 & 0.289 & 0.510 & 0.780 & 0.342 & 0.312 \\
\hline & RESP3 & 0.361 & 0.450 & 0.817 & 0.317 & 0.297 \\
\hline & RESP4 & 0.370 & 0.255 & 0.677 & 0.242 & 0.257 \\
\hline \multirow{4}{*}{ Accessibility } & ACC1 & 0.444 & 0.538 & 0.451 & 0.766 & 0.518 \\
\hline & $\mathrm{ACC} 2$ & 0.533 & 0.446 & 0.428 & 0.814 & 0.478 \\
\hline & ACC3 & 0.417 & 0.309 & 0.323 & 0.691 & 0.305 \\
\hline & ACC4 & 0.506 & 0.510 & 0.473 & 0.762 & 0.518 \\
\hline \multirow{4}{*}{$\begin{array}{l}\text { Overall Perceived } \\
\text { Service Quality }\end{array}$} & OPSQ1 & 0.510 & 0.404 & 0.404 & 0.397 & 0.760 \\
\hline & OPSQ2 & 0.511 & 0.498 & 0.466 & 0.436 & 0.797 \\
\hline & OPSQ3 & 0.584 & 0.521 & 0.548 & 0.555 & 0.828 \\
\hline & OPSQ4 & 0.432 & 0.417 & 0.424 & 0.392 & 0.605 \\
\hline
\end{tabular}


Table 2: T value results

\begin{tabular}{|c|c|c|c|c|c|}
\hline Constructs & Items & Loadings & $\begin{array}{l}\text { Standard } \\
\text { Error }\end{array}$ & T Value & P Value \\
\hline \multirow{5}{*}{ Website Design } & WEB1 & 0.574 & 0.055 & 10.505 & 0.000 \\
\hline & WEB2 & 0.630 & 0.049 & 12.877 & 0.000 \\
\hline & WEB3 & 0.804 & 0.024 & 33.318 & 0.000 \\
\hline & WEB4 & 0.783 & 0.025 & 31.410 & 0.000 \\
\hline & WEB5 & 0.717 & 0.028 & 25.524 & 0.000 \\
\hline \multirow{6}{*}{ Trust } & TRST1 & 0.782 & 0.020 & 39.028 & 0.000 \\
\hline & TRST2 & 0.802 & 0.019 & 42.128 & 0.000 \\
\hline & TRST3 & 0.833 & 0.017 & 48.798 & 0.000 \\
\hline & TRST4 & 0.630 & 0.035 & 18.029 & 0.000 \\
\hline & TRST5 & 0.751 & 0.022 & 33.976 & 0.000 \\
\hline & TRST6 & 0.690 & 0.031 & 22.447 & 0.000 \\
\hline \multirow{4}{*}{ Responsiveness } & RESP1 & 0.775 & 0.021 & 36.481 & 0.000 \\
\hline & RESP2 & 0.780 & 0.019 & 41.218 & 0.000 \\
\hline & RESP3 & 0.817 & 0.016 & 52.177 & 0.000 \\
\hline & RESP4 & 0.677 & 0.032 & 21.243 & 0.000 \\
\hline \multirow{4}{*}{ Accessibility } & ACC1 & 0.766 & 0.025 & 31.227 & 0.000 \\
\hline & ACC2 & 0.814 & 0.018 & 45.821 & 0.000 \\
\hline & ACC3 & 0.691 & 0.029 & 23.906 & 0.000 \\
\hline & ACC4 & 0.762 & 0.021 & 36.754 & 0.000 \\
\hline \multirow{4}{*}{$\begin{array}{l}\text { Overall Perceived } \\
\text { Service Quality }\end{array}$} & OPSQ1 & 0.760 & 0.022 & 34.837 & 0.000 \\
\hline & OPSQ2 & 0.797 & 0.024 & 33.716 & 0.000 \\
\hline & OPSQ3 & 0.828 & 0.014 & 58.409 & 0.000 \\
\hline & OPSQ4 & 0.605 & 0.037 & 16.337 & 0.000 \\
\hline
\end{tabular}

\subsubsection{THE CONVERGENT VALIDITY}

According to Bagozzi and Yi (1988) and Hair et al., (2010), the definition of convergent validity is to indicate the extent to which a set of items converges in measuring a particular construct. As shown in Table 3 below the composite reliability of each construct is at least 0.831 exceeding the cut off value of 0.7. Additionaly, the values of average variance extracted (AVE) for each construct is at least 0.5 (Fornell \& Larcker, 1981; Hair et al., 2010), and it is ranging from 0.500 to 0.583 illustrating a good level of construct validity related to the used measures (Barclay et al., 1995). The convergent validity of the remaining model is confirmed from these outcomes. 
Table 3: Convergent validity analysis

\begin{tabular}{|c|c|c|c|c|c|}
\hline Constructs & Items & Loadings & $\begin{array}{l}\text { Cronbach's } \\
\text { Alpha }\end{array}$ & $\mathbf{C R a}$ & AVEb \\
\hline \multirow{5}{*}{ Website Design } & WEB1 & 0.574 & \multirow{5}{*}{0.757} & \multirow{5}{*}{0.831} & \multirow{5}{*}{0.500} \\
\hline & WEB2 & 0.630 & & & \\
\hline & WEB3 & 0.804 & & & \\
\hline & WEB4 & 0.783 & & & \\
\hline & WEB5 & 0.717 & & & \\
\hline \multirow{6}{*}{ Trust } & TRST1 & 0.782 & \multirow{6}{*}{0.844} & \multirow{6}{*}{0.885} & \multirow{6}{*}{0.564} \\
\hline & TRST2 & 0.802 & & & \\
\hline & TRST3 & 0.833 & & & \\
\hline & TRST4 & 0.630 & & & \\
\hline & TRST5 & 0.751 & & & \\
\hline & TRST6 & 0.690 & & & \\
\hline \multirow{4}{*}{ Responsiveness } & RESP1 & 0.775 & \multirow{4}{*}{0.760} & \multirow{4}{*}{0.848} & \multirow{4}{*}{0.583} \\
\hline & RESP2 & 0.780 & & & \\
\hline & RESP3 & 0.817 & & & \\
\hline & RESP4 & 0.677 & & & \\
\hline \multirow{4}{*}{ Accessibility } & $\mathrm{ACC} 1$ & 0.766 & \multirow{4}{*}{0.755} & \multirow{4}{*}{0.845} & \multirow{4}{*}{0.577} \\
\hline & $\mathrm{ACC} 2$ & 0.814 & & & \\
\hline & ACC3 & 0.691 & & & \\
\hline & ACC4 & 0.762 & & & \\
\hline \multirow{4}{*}{$\begin{array}{l}\text { Overall Perceived } \\
\text { Service Quality }\end{array}$} & OPSQ1 & 0.760 & \multirow{4}{*}{0.738} & \multirow{4}{*}{0.837} & \multirow{4}{*}{0.566} \\
\hline & OPSQ2 & 0.797 & & & \\
\hline & OPSQ3 & 0.828 & & & \\
\hline & OPSQ4 & 0.605 & & & \\
\hline
\end{tabular}

a: Composite Reliability: $\mathrm{CR}=\left(\sum\right.$ factor loading $) 2 /\left\{\left(\sum\right.\right.$ factor loading $\left.) 2\right)+\sum$ (variance of error $\left.)\right\}$ b: Average Variance Extracted: AVE $=\left(\sum\right.$ factor loading $) 2 /\left\{\sum\right.$ (factor loading $) 2+\sum$ variance of error)\}

\subsubsection{THE DISCRIMINATE VALIDITY}

The definition of discriminate validity is the degree to which a set of items can distinguish a construct from other constructs. Thus, according to Compeau et al., (1999) if compared the shared variance of construct with the shared variance of other constructs is supposed to be greater value comparing to other construct. Fornell and Larcker (1981) suggested a criterion to examine the discriminant validity. As illustrated in Table 4, the square roots of AVE (average variance extracted) are being considered diagonal elements and the variable correlation is given below the diagonal elements. If the diagonal elements are being considered higher than the elements in other off diagonal in their related columns and rows then we can make the comparison and assume the discriminant validity. Furthermore, the results in the correlation matrix illustrated in Table 4 ensure that the discriminant validity is confirmed. 
Table 4: The Discriminate Validity

\begin{tabular}{|c|c|c|c|c|c|}
\hline Constructs & (1)WEB & (2)TRST & (3)RESP & (4)ACC & (5)OPSQ \\
\hline 1) Website Design & $\mathbf{0 . 7 0 7}$ & & & & \\
\hline 2) Trust & 0.546 & 0.751 & & & \\
\hline 3) Responsiveness & 0.241 & 0.334 & 0.764 & & \\
\hline 4) Accessibility & 0.394 & 0.504 & 0.466 & 0.760 & \\
\hline $\begin{array}{l}\text { 5) Overall Perceived Service } \\
\text { Quality }\end{array}$ & 0.334 & 0.388 & 0.563 & 0.608 & 0.752 \\
\hline
\end{tabular}

\subsubsection{PREDICTIVE RELEVANCE OF THE MODEL}

To gain the good assessing and predictive power of the proposed research model, R2 were used as well as the Cross-Validated redundancy. R2 is defined as a value that indicates the amount of variance in the endogenous variable that is explained by the exogenous variables. Table 5 showed that R2 value is $57.5 \%$ of the overall perceived service quality and was explained by website design, trust, responsiveness, and accessibility dimensions. In this study, the results related to the quality of prediction of the model, as discussed in Table 5 revealed that the Cross Validated Communality related to overall perceived service quality (OPSQ) was 0.566. And the Cross Validated Redundancy value was 0.321. And the Cross Validated Communality value was 0.566. These values are more than zero indicating an adequate predictive validity of the model based on the criteria mentioned by Fornell and Cha (1994). These values are more than zero indicating an adequate predictive validity of the model based on the criteria mentioned by Fornell and Cha (1994).

Table 5: Prediction Relevance of the Model

\begin{tabular}{lllll}
\hline Constructs & Variable Type & R Square & $\begin{array}{l}\text { Cross-validated } \\
\text { Redundancy }\end{array}$ & $\begin{array}{l}\text { Cross-validated } \\
\text { Communality }\end{array}$ \\
\hline OPSQ & Endogenous & 0.575 & 0.321 & 0.566 \\
\hline
\end{tabular}

\subsubsection{5. (GoF) GOODNESS OF FIT OF THE MODEL}

Unlike CB-SEM, PLS-SEM has only one measure of goodness of fit which was defined to be the global fit measure by Tenenhaus et al. (2005). It is the geometric mean of the average variances extracted and the average R2 for the endogenous variables as given in the following formula:

$G o F=\sqrt{\left(R^{2} * A V E\right)}$

Particularly, the GoF value of this model was found to be 0.657 which is considered large when compared to the baseline values suggested by Wetzels et al., $(2009)^{52}$ ( small $=0.1$, medium $=0.25$, large $=0.36$ ). The results showed that the model goodness of fit measure based on the average variance explained is large which indicate an adequate level of global PLS model validity. 


\subsubsection{THE HYPOTHESIS TESTING}

After establishing the measurement model, the next step was to test the hypotheses of the study by running PLS Bootstrapping in SmartPLS 2.0, the cases that were used for analysis in this study was 618.

Table 6: The Results of the Hypothesis Testing

\begin{tabular}{|l|l|l|l|l|l|l|}
\hline No & Hypotheses & $\begin{array}{l}\text { Path } \\
\text { Coefficient }\end{array}$ & $\begin{array}{l}\text { Standard } \\
\text { Error } \\
\text { (STERR) }\end{array}$ & $\begin{array}{l}\text { T } \\
\text { value }\end{array}$ & $\begin{array}{l}\text { P } \\
\text { value }\end{array}$ & Decision \\
\hline $\mathbf{1}$ & WEB -> OPSQ & 0.010 & 0.034 & 0.293 & 0.385 & $\begin{array}{l}\text { Not } \\
\text { Supported }\end{array}$ \\
\hline $\mathbf{2}$ & TRST -> OPSQ & 0.003 & 0.033 & 0.100 & 0.460 & $\begin{array}{l}\text { Not } \\
\text { Supported }\end{array}$ \\
\hline $\mathbf{3}$ & RESP -> OPSQ & $0.106 * * *$ & 0.041 & 2.573 & 0.005 & Supported \\
\hline $\mathbf{4}$ & ACC -> OPSQ & $0.126 * * *$ & 0.046 & 2.724 & 0.003 & Supported \\
\hline
\end{tabular}

As shown in Table 6 the website design (WEB) has a positive and does not have a significant effect on the overall perceived service quality (OPSQ) large of the 0.01 level of significance $(\beta=$ $0.010, t=0.293, p>0.1)$. The results also show that trust (TRST) was has a positive and does not have significant effect on the overall perceived service quality (OPSQ) large of the 0.01 level of significance $(\beta=0.003, t=0.100, p>0.1)$. In addition, the results also show that responsiveness (RESP) has a positive and there are a significant effect on the overall perceived service quality (OPSQ) large of the 0.01 level of significance $(\beta=0.106, \mathrm{t}=2.573, \mathrm{p}<0.01)$. Finally, the accessibility (ACC) has a positive and significant effect on the levels of the overall perceived service quality (OPSQ) at the 0.01 level of significance $(\beta=0.126, t=2.724, p<0.01)$. Therefore, these results supported the hypotheses of the study $\mathrm{H} 3$, and $\mathrm{H} 4$ and the result does not support hypothesis $\mathrm{H} 1$, and $\mathrm{H} 2$ as reported in table 6 above.

\section{DISCUSSION AND CONCLUSIONS}

To examine the effect of $\mathrm{m}$-commerce service quality dimensions (website design, responsiveness, and trust), and system quality dimension (accessibility) on overall perceived service quality in mcommerce by customers was the foremost purpose of the study. This research is important since it extends the SERVQUAL model which has many similarities with IS model being used to benchmark and compare several studies that have initially combined the two models. In addition, the importance of this study cannot be overrated as its benefits' cut across many stakeholders since it can be regarded as among the initial studies that delve into the factors that helps to capture the interest of customers towards using of mobile phone technology for the purpose of commercial transactions.

This research has brought to light many practical and theoretical issues of m-commerce service quality. Importantly, the research has discovered some possible and positive factors that make the pursuance of $\mathrm{m}$-commerce service quality to be a worthy exercise. In this respect, therefore, this 
research has therefore challenged the entire information system research to continue to investigate into those factors that can influence mobile commerce service quality by applying new applications that match background and preferences of users.

Future research could carry out similar studies with respect to OPSQ in developing countries because only a few attempts of such have been made. Additionally, a comparative study between developing and developed countries concerning OPSQ can be carried out. Moreover, this study used only questionnaire to collect data, other researchers can use qualitative method - in-depth interview - with a view of getting more suitable variables that could impact customers overall perceived m-commerce. This can be better achieved when the researcher builds a trusted relationship with them and speaks their language. The findings of this study might be of a great value to creating new knowledge, awareness and benefits that can be derived from using mobile transaction especially among customers and vendors. Creating such awareness will help to foster a better understanding and practices of $\mathrm{m}$-commerce and would help in increasing the agility in power of purchasing of the customers and organizations business efficiency.

\section{REFERENCES}

[1] Aladwani, A. M., \& Palvia, P. C. (2002). Developing and validating an instrument for measuring user-perceived web quality. Information \& Management, 39(6), 467-476.

[2] Alfawaer, Z. M., Awni, M., \& Al-Zoubi, S. (2011). Mobile e-ticketing reservation system for Amman International Stadium in Jordan. International Journal of Academic Research, 3(1), 848852.

[3] Bagozzi, R. P., \& Yi, Y. (1988). On the evaluation of structural equation models. Journal of the academy of Marketing Science, 16(1), 74-94.

[4] Barclay, D., Higgins, C., \& Thompson, R. (1995). The partial least squares (PLS) approach to causal modeling: Personal computer adoption and use as an illustration. Technology studies, 2(2), 285-309.

[5] Chae, M., Kim, J., Kim, H., \& Ryu, H. (2002). Information quality for mobile Internet services: A theoretical model with empirical validation. Electronic Markets, 12(1), 38-46.

[6] Chin, W. W. (1998). The partial least squares approach to structural equation modeling. Modern methods for business research, 295(2), 295-336.

[7] Cho, N., \& Park, S. (2001). Development of electronic commerce user-consumer satisfaction index (ECUSI) for Internet shopping. Industrial Management \& Data Systems, 101(8), 400-405.

[8] Gerpott, T. J., Rams, W., \& Schindler, A. (2001). Customer retention, loyalty, and satisfaction in the German mobile cellular telecommunications market. Telecommunications Policy, 25(4), 249-269.

[9] Compeau, D., Higgins, C. A., \& Huff, S. (1999). Social cognitive theory and individual reactions to computing technology: A longitudinal study. MIS quarterly, 23(2), 145-158.

[10] Dabholkar, P. A. (1996). Consumer evaluations of new technology-based self-service options: an investigation of alternative models of service quality. International Journal of research in Marketing, 13(1), 29-51.

[11] E-paymentsMerchantIntiative. (2011). Concept position paper: Online Payments in Europe Key issues and requirements of Web Merchants in Europe (pp. 1-9). 
[12] Euromonitor. (2011). Starbucks Mobile App Has Ability to Change M-Commerce Landscape in the U.S Retrieved March/30/2012, from http://blog.euromonitor.com/2011/06/starbucksmobile-app-has-ability-to-change-m-commerce-landscape-in-the-us.html

[13] Fornell, C., \& Cha, J. (1994). Partial least squares. Advanced methods of marketing research, 407(6), 52-78.

[14] Fornell, C., Johnson, M. D., Anderson, E. W., Cha, J., \& Bryant, B. E. (1996). The American customer satisfaction index: nature, purpose, and findings. The Journal of Marketing, 60(4), 7-18. [15] Fornell, C., \& Larcker, D. F. (1981). Evaluating structural equation models with unobservable variables and measurement error. Journal of marketing research, 5(9), 39-50.

[16] Ghose, S., \& Dou, W. (1998). Interactive functions and their impacts on the appeal of Internet presence sites. Journal of Advertising Research, 38(2), 29-44.

[17] Goi, C. L., \& Ng, P. Y. (2011). Perception of Young Consumers on Mobile Phone Applications in Malaysia. World Applied Sciences Journal, 15(1), 47-55.

[18] Gummerus, J., Liljander, V., Pura, M., \& Van Riel, A. (2004). Customer loyalty to contentbased web sites: the case of an online health-care service. Journal of Services Marketing, 18(3), 175-186.

[19] Hair, J. J. F., Black, W. C., Babin, B. J., \& Anderson, R. E. (2010). Multivariate Data Analysis. A Global Perspective. London: Pearson Education.

[20] Jahanshahi, A. A., Mirzaie, A., \& Asadollahi, A. (2011). Mobile Commerce Beyond Electronic Commerce: Issue And Challenges. Asian Journal of Business and Management Sciences, 1(2), 119-129.

[21] Kar, E., Muniafu, S., \& Wang, Y. (2006). Mobile services used in unstable environments: design requirements based on three case studies. Paper presented at the Proceedings of the 8th international conference on Electronic commerce: The new e-commerce: innovations for conquering current barriers, obstacles and limitations to conducting successful business on the internet, Fredericton, Canada.

[22] Kaynama, D. S. A., \& Black, C. I. (2000). A proposal to assess the service quality of online travel agencies: An exploratory study. Journal of Professional Services Marketing, 21(1), 63-88. [23] Kim, M. K., Park, M. C., \& Jeong, D. H. (2004). The effects of customer satisfaction and switching barrier on customer loyalty in Korean mobile telecommunication services. Telecommunications Policy, 28(2), 145-159.

[24] Kimery, K. M., \& McCard, M. (2002). Third-Party Assurance: Mapping the Road to Trust in E-retailing. Journal of Information Technology Theory and Application, 4(2), 63-82.

[25] Kinnally, W., Lacayo, A., McClun, S. and Sapolsky, B. (2008), Getting up on the download: college students' motivation for acquiring music via the web. New Media Society, 10(3), 893-913. [26] Landers, P. (2002). From E-Learning to MLearning, Ericsson. 2002.

[27] Lee, G.-G., \& Lin, H.-F. (2005). Customer perceptions of e-service quality in online shopping. International Journal of Retail \& Distribution Management, 33(2), 161-176.

[28] Lee, J., Lee, J., \& Feick, L. (2001). The impact of switching costs on the customer satisfactionloyalty link: mobile phone service in France. Journal of Services Marketing, 15(1), 35-48.

[29] Liljander, V., Van Riel, A. C., \& Pura, M. (2002). Customer satisfaction with e-services: the case of an online recruitment portal. Yearbook of Services Management, 33(5), 407-432.

[30] Lim, H., Widdows, R., \& Park, J. (2006). M-loyalty: winning strategies for mobile carriers. Journal of Consumer Marketing, 23(4), 208-218.

[31] Loiacono, E. T., Watson, R. T., \& Goodhue, D. L. (2002). WebQual: A measure of website quality. Marketing theory and applications, 13(3), 432-438. 
[32] Lynch, D. C., \& Lundquist, L. (1996). Digital money: the new era of Internet commerce. New York, NY: John Wiley \& Sons, Inc.

[33] Maister, D. H. (1985). The service encounter: Managing employee/customer interaction in service business Lexington, MA: Lexington Books. Free Press.

[34] O'Cass, A., \& Carlson, J. (2012). An e-retailing assessment of perceived website-service innovativeness: Implications for website quality evaluations, trust, loyalty and word of mouth. Australasian Marketing Journal (AMJ), 20(3), 28-36.

[35] Papanikolaou, K., \& Mavromoustakos, S. (2006). Critical success factors for the development of mobile learning applications. Paper presented at the 24th IASTED International MultiConference Internet and Multimedia Systems and applications Innsbruck, Austria.

[36] Parasuraman, A., Zeithaml, V. A., \& Berry, L. (1988). SERVQUAL: a multiple-item scale for measuring consumer perceptions of service quality. Retailing: Crit Concepts Bk2, 64(1), 12-40.

[37] Rao, B., \& Minakakis, L. (2003). Evolution of mobile location-based services. Communications of the ACM, 46(12), 61-65.

[38] Riel, A. C., Liljander, V., \& Jurriens, P. (2001). Exploring consumer evaluations of eservices: a portal site. International Journal of Service Industry Management, 12(4), 359-377.

[39] Reichheld, F. F., \& Schefter, P. (2000). E-loyalty: your secret weapon on the web. Harvard business review, 78(4), 105-113.

[40] Seth, A., Momaya, K., \& Gupta, H. (2005). An exploratory investigation of customer loyalty and retention in cellular mobile communication. Journal of Services Research, 1(Special Issue), 173-185.

[41] Siau, K., Lim, E. P., \& Shen, Z. (2001). Mobile commerce: Promises, challenges and research agenda. Journal of Database Management (JDM), 12(3), 4-13.

[42] Sohn, C. S. (2000). Customer evaluation of Internet-based service quality and intention to reuse internet-based services. Unpublished doctoral dissertation, Southern Illinois University, Carbondale, Illinois.

[43] Tenenhaus, M., Vinzi, V. E., Chatelin, Y.-M., \& Lauro, C. (2005). PLS path modeling. Computational statistics \& data analysis, 48(1), 159-205.

[44] Tiwari, R., Buse, S., \& Herstatt, C. (2006). Mobile banking as business strategy: Impact of mobile technologies on customer behaviour and its implications for banks. Paper presented at the Technology Management for the Global Future, 2006. PICMET 2006.

[45] Turel, O., \& Serenko, A. (2006). Satisfaction with mobile services in Canada: An empirical investigation. Telecommunications Policy, 30(5-6), 314-331.

[46] Udo, G. J., Bagchi, K. K., \& Kirs, P. J. (2010). An assessment of customers'e-service quality perception, satisfaction and intention. International Journal of Information Management, 30(6), 481-492.

[47] Wang, Y. S. (2003). The adoption of electronic tax filing systems: an empirical study. Government Information Quarterly, 20(4), 333-352.

[48] Wang, Y. S. (2003). Assessment of learner satisfaction with asynchronous electronic learning systems. Information \& Management, 41(1), 75-86.

[49] Wolfingbarger, M., \& Gilly, M. (2003). eTailQ: dimensionalizing, measuring and predicting etail quality. Journal of Retailing, 79(3), 183-198.

[50] Yun, D. K., Kim, K. Y., \& Ko, H. S. (2005). Customer expectation level in mobile data services. Paper presented at the Proceedings of the 7th international conference on Human computer interaction with mobile devices \& services. 259-262. 